УДК:338.242.

DOI: https://doi.org/10.32689/2618-0065-2020-2(4)-214-227

Лисачок Алла Василівна, аспірантка кафедри державного управління Львівського регіонального інституту державного управління Національної академії державного управління при Президентові України, тел.:+380975111820, e-mail: lysachok96@ukr.net, https//orcid.org/0000-00025716-487X

\title{
СУЧАСНИЙ СТАН НОРМАТИВНО-ПРАВОВОГО РЕГУЛЮВАННЯ ІНВЕСТИЦЙНОЇ БЕЗПЕКИ ДЕРЖАВИ
}

Анотація. В статті зазначено, що нормативно-правове регулювання інвестиційної безпеки надає гарантії та захист для інвесторів, які можуть бути недобросовісними, тобто відноситись до так званих псевдоінвесторів. Виявлено, що правове регулювання базується на використанні методів юридичного права, які регулюють відносини між державою та громадянами, органами державної влади та суспільством, а також окреслюють коло повноважень та визначають статус органів державного управління. Надано трактування дефініції поняттю “інвестиційна безпека", а також наведено власне визначення даного поняття. Визначено, що до форм нормативноправового регулювання відносяться Конституція, закони, укази Президента, підзаконні правові нормативні акти. До структури правового регулювання включають законодавче регулювання, нормативне визначення елементів, внутрішньо системне нормативне регулювання процесів, самоврядування, правоохоронне регулювання управлінських процесів. Наведено, що нормативно-правове забезпечення інвестиційної політики в Україні було засновано разом 3 досягненням держави незалежності. Доведено, що особливістю вітчизняного інвестиційного законодавства $\epsilon$ те, що окремі аспекти в інвестиційній сфері, окрім нормативно-правових актів, регулюються також нормами господарського, податкового, бюджетного, митного, цивільного й земельного законодавства, правовими актами про приватизацію, цінні папери та фондовий ринок, концесію тощо. Окреслено, що дана нормативно-правова система держави, яка сформувалась свідчить про те, що на сьогодні держава вживає низку заходів, які мають на меті створення в Україні сприятливих умов здійснення інвестиційної діяльності саме шляхом закріплення на законодавчому рівні принципів та правил іiі здійснення.

Ключові слова: інвестиції, інвестор, інвестиційна безпека, органи державної влади, нормативно-правове регулювання.

Lysachok Alla Vasylivna, graduate student of the Department of Public Administration The Lviv regional Institute for public administration The National 
academy of public administration, the President of Ukraine, tel.: +380975111820, email: lysachok96@ukr.net, https//orcid.org/0000-0002-5716-487X

\title{
THE CURRENT STATUS OF THE REGULATORY AND LEGAL REGULATION OF THE STATE INVESTMENT SECURITY
}

\begin{abstract}
The article states that the legal regulation of investment security provides guarantees and protection for investors who may be unscrupulous, that is, relate to the so-called pseudo-investors. It was revealed that legal regulation is based on the use of legal law methods that regulate relations between the state and citizens, state authorities and society, as well as determine the terms of reference and determine the status of government bodies. Interpretations of the definition are given to the concept of "investment security", and their own definition of this concept is also given. It is determined that the Constitution, laws, decrees of the President, subordinate legal normative acts belong to the forms of legal regulation. The structure of legal regulation includes legislative regulation, normative definition of elements, internal systematic normative regulation of processes, self-government, law enforcement regulation of administrative processes. It is shown that the legal support of the investment policy in Ukraine was founded along with the achievement of the state of independence. It has been proved that the peculiarity of the domestic investment legislation is that certain aspects in the investment sphere, in addition to regulatory legal acts, are also regulated by the norms of economic, tax, budget, customs, civil and land laws, legal acts on privatization, securities and the stock market, concession and the like. It is determined that this regulatory system of the state, which has formed, indicates that today the state is taking a number of measures aimed at creating favorable conditions for investment activities in Ukraine precisely by fixing at the legislative level the principles and rules for its implementation.
\end{abstract}

Keywords: investments, investor, investment security, government, legal regulation.

Постановка проблеми. Впродовж років незалежності України, органи державної влади переймали досвід провідних країн світу, щодо забезпечення інвестиційної діяльності, а зокрема, щодо регулювання держави; виокремлювали умови щодо ефективного розвитку інвестиційного ринку України; залучали іноземні інвестиції в економіку країни при цьому не створюючи сприятливого інвестиційного поля для внутрішніх інвесторів; очікували досягнення критичного значення індикаторів інвестиційної безпеки, а при їх досягненні гранично допустимих значень запроваджували міри, які не змогли вчасно вирішити проблему. Крім цього відсутній дієвий механізм визначення добросовісності інвесторів, щодо інвестування в економіку України, тобто система моніторингу працює не на повну потужність. Нормативно-правове регулювання інвестиційної безпеки надає гарантії та захист для інвесторів, які можуть бути недобросовісними, тобто відноситись до так званих псевдоінвесторів. Вищенаведене зумовлює необхідність 
визначення сучасного стану нормативно-правової бази регулювання інвестиційної безпеки держави.

Аналіз останніх досліджень і публікацій. Проблеми нормативноправового забезпечення інвестиційної діяльності розглянуті в працях таких вчених як: Л. Акімової, О. Барановського, В. Білоус, І. Губенко, З. Гбур, Г. Данилюка, Т. Затонацької, В. Кириленка, А. Лисачок, А. Макухи, О. Малютіна, С. Міщук, І. Москаль, С. Мошенського, Я. Недашківського, Н. Нижник, К. Подгорної, Л. Руснак, Г. Ситник, А. Ставицького, С. Ткаленко, та ін.

Однак інтереси їх досліджень перебувають в сфері аналізу інвестиційної діяльності, тобто нормативно-правове регулювання інвестиційної безпеки $є$ недостатньо розглянутим, що обумовлює актуальність дослідження.

Метою статті $\epsilon$ визначення сучасного стану нормативно-правової бази щодо регулювання інвестиційної безпеки держави.

Виклад основного матеріалу. Правове регулювання базується на використанні методів юридичного права, які регулюють відносини між державою та громадянами, органами державної влади та суспільством, а також окреслюють коло повноважень та визначають статус органів державного управління. Вищенаведені процеси створюють сприятливі умови для правильного регулювання взаємовідносин між учасниками державноуправлінського процесу. Інвестиційна безпека є одним із важливих складових економічної безпеки, то варто розглянути підходи щодо визначення даного поняття. Оскільки в економічній літературі відсутнє єдине визначення поняття “інвестиційна безпека”, доцільно розглянути основні дефініції останнього для кращого розуміння даної проблематики.

Дослідник С. Мошенський вважає, що інвестиційна безпека - це особлива підсистема економічної безпеки, що створює передумови для найкращого використання соціально-економічних відносин у розвитку i науково-технічному відновленні продуктивних сил суспільства через активну інвестиційну діяльність [1, с. 167].

А. Макух та Л. Руснак розуміють під інвестиційною безпекою процес забезпечення такого стану інвестиційної сфери, за якого економіка здатна зберігати й підтримувати достатній рівень інвестиційних ресурсів в умовах дії внутрішніх і зовнішніх загроз, що $є$ необхідним для забезпечення стійкого розвитку й соціально-економічної стабільності країни, зростання конкурентоспроможності їі економіки та добробуту населення [2].

I. Губенко під інвестиційною безпекою розуміє стан організації інвестиційних процесів, за якого забезпечується оптимальне задоволення поточних потреб економіки в капітальних вкладеннях за обсягом і структурою 3 урахуванням ефективного використання та повернення коштів, які інвестуються, досягнення оптимального співвідношення між розмірами 
іноземних інвестицій у країну $\mathrm{i}$ вітчизняних за кордон, підтримання позитивного національного платіжного балансу [3, с. 76].

Дослідник Акімова Л.М вважає, що економічна безпека країни є однією 3 важливих та ключових систем, в свою чергу вона є підсистемою національної безпеки, зважаючи на це вона має складну структуру, оскільки складається 3 певних складових. В працях багатьох дослідників ми можемо побачити наступні структурні елементи 3 яких складається економічна безпека: інвестиційна безпека, сировинно-ресурсна безпека; воєнна; енергетична безпека; фінансова безпека; соціальна безпека; інноваційно-технологічна безпека; продовольча безпека; зовнішньоекономічна безпека; макроекономічна безпека [4-9]. Крім того, Акімова Л.М. вважає, що інвестиційна безпека як складова економічної безпеки сприяє створенню надійної та забезпеченої всіма необхідними засобами держави, захищеності національно-державних інтересів у сфері економіки [10-16].

Таким чином, під інвестиційною безпекою, варто розуміти такий стан економіки при якому інвестиційні ресурси, інвестори та всі складові інвестиційного процесу захищені від негативних внутрішніх та зовнішніх чинників.

Варто розглянути основні форми нормативно-правового регулювання інвестиційної безпеки України (рис.1 ).

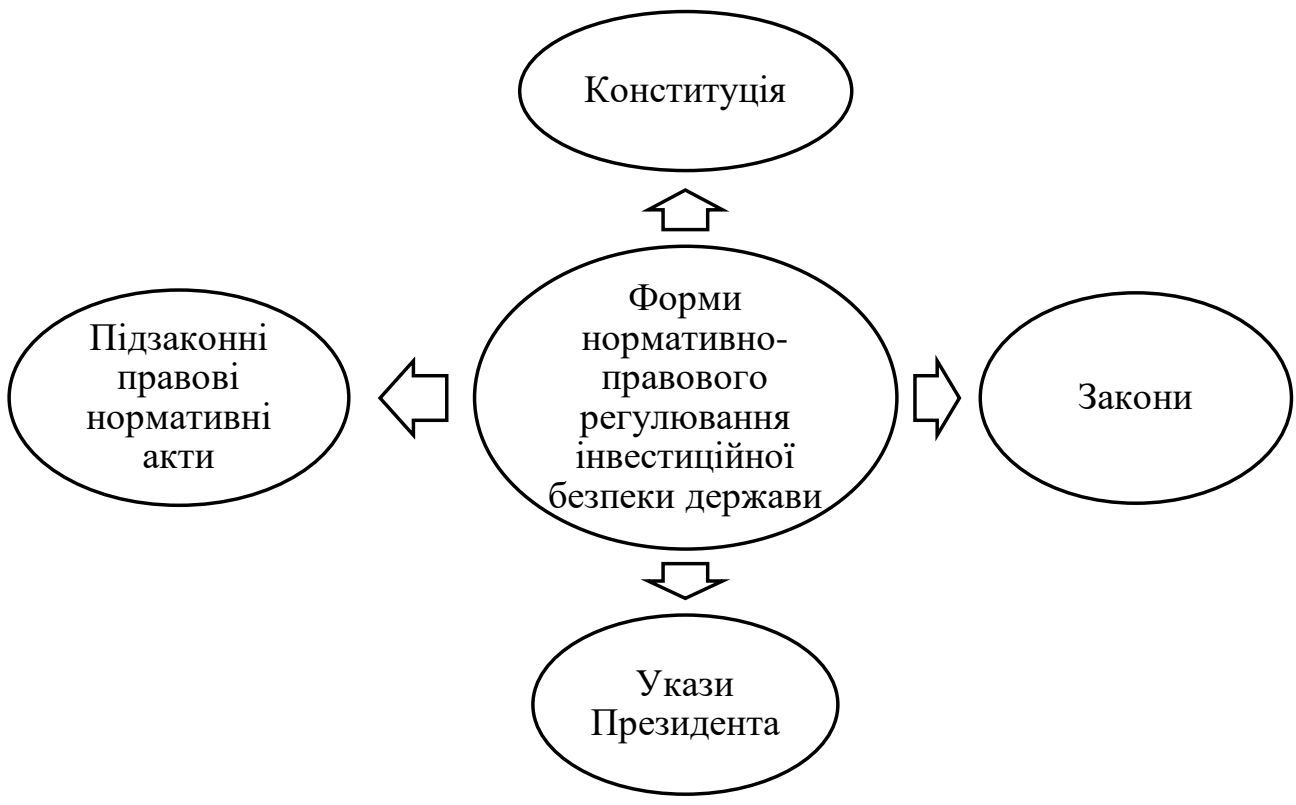

Рис.1. Форми нормативно-правового регулювання інвестиційної безпеки держави

Розробка автора [4-16].

3 рис. 1. бачимо, що до форм нормативно-правового регулювання відносяться Конституція, закони, укази Президента, підзаконні правові нормативні акти. До структури правового регулювання включають законодавче регулювання, нормативне визначення елементів, внутрішньо 
системне нормативне регулювання процесів, самоврядування, правоохоронне регулювання управлінських процесів.

Нормативно-правове забезпечення інвестиційної політики в Україні було засновано в 1991 р. Законом України “Про інвестиційну діяльність”. Йшлося про створення пільгових умов для інвесторів, які працюють у пріоритетних сферах, про державне регулювання інвестиційної діяльності за допомогою податкової, кредитної, амортизаційної, цінової політики, а також державної фінансової підтримки, застосування державного замовлення у сфері капітального будівництва, страховий захист інвестицій [17].

На подальший розвиток механізму економічного регулювання інвестиційного процесу всі його учасники покладали надії з появою “Концепції регулювання інвестиційної діяльності в умовах ринкової трансформації економіки", затвердженої постановою Кабінету міністрів у 1995 р. Вищенаведена Концепція розглядає такі важливі питання, що стосуються інвестиційної діяльності як: державні пріоритети в інвестиційній діяльності; основні засади регулювання інвестиційної діяльності; шляхи залучення інвестицій, а також механізми реалізації інвестиційної політики [18].

За допомогою впровадження в дію Закону України "Про зовнішньоекономічну діяльність" від 1991 р. на території України запропоновано впровадити такі правові режими для іноземних суб єктів господарської діяльності, а саме: національний режим; режим найбільшого сприяння; спеціальний режим [19]. Крім цього даний Закон надає дефініцію поняттю "іноземні інвестиції'. Відповідно до цього Закону, одним 3 підпунктом державного регулювання зовнішньоекономічної діяльності $\epsilon$ створення рівних можливостей для суб'єктів зовнішньоекономічної діяльності розвивати всі види підприємницької діяльності незалежно від форм власності та всі напрями використання доходів і здійснення інвестицій.

Ще одним важливим Законом, що допомагає врегульовувати питання, які стосуються інвестицій є Закон України "Про режим іноземного інвестування" від 1996 р. [20] За допомогою останнього визначаються основні види та форми іноземних інвестицій, також зауважено таке основне питання як оцінка іноземних інвестицій. Крім того, для іноземних інвесторів на території України встановлюється національний режим інвестиційної та іншої господарської діяльності, за винятками, передбаченими законодавством України та міжнародними договорами України. Для окремих суб’єктів підприємницької діяльності, які здійснюють інвестиційні проекти із залученням іноземних інвестицій, що реалізуються відповідно до державних програм розвитку пріоритетних галузей економіки, соціальної сфери i територій, може встановлюватися пільговий режим інвестиційної та іншої господарської діяльності.

Важливим $\epsilon$ також те, що якщо в подальшому спеціальним законодавством України про іноземні інвестиції будуть змінюватися гарантії 
захисту іноземних інвестицій, то протягом десяти років 3 дня набрання чинності таким законодавством на вимогу іноземного інвестора застосовуються державні гарантії захисту іноземних інвестицій. Іноземні інвестиції в Україні не підлягають націоналізації. Державні органи не мають права реквізувати іноземні інвестиції, за винятком випадків здійснення рятівних заходів у разі стихійного лиха, аварій, епідемій, епізоотій. Зазначена реквізиція може бути проведена на підставі рішень органів, уповноважених на це Кабінетом Міністрів України.

Слід звернути увагу, що значну частину вітчизняного законодавства становлять міжнародні правові акти, учасником яких є Україна: багатосторонні міжнародні угоди, конвенції, які спрямовані як на захист іноземних інвестицій, так і на врегулювання інших питань. Для регулювання інвестиційних спорів, які виникають між державами наразі ратифікована "Конвенція про порядок вирішення інвестиційних спорів між державами та іноземними особами” від 1965 р. [21] За допомогою вищезгаданої Конвенції врегульовуються спори між країнами, а також описується певно процедура вирішення цих спорів.

Розглянувши Закон України "Про внесення змін до деяких законів України з метою усунення випадків ухилення окремих підприємств, створених за участю іноземних інвесторів, від сплати податків, зборів (обов’язкових платежів)" від 2001 р. [22] ми можемо дізнатись, що судові рішення про застосування до підприємств 3 іноземними інвестиціями, їхніх дочірніх підприємств, а також філій, відділень та інших відокремлених підрозділів державних гарантій захисту інвестицій, винесені на підставі законодавчих актів підлягають виконанню виключно в частині, що не суперечить цьому Закону.

Законодавство України надає інвестору, в тому числі іноземному, досить широкі можливості у виборі об єкта інвестування, видів інвестицій, залучення інших учасників до реалізації інвестиційних проектів. При цьому втручання державних органів та посадових осіб у реалізацію договірних відносин між суб’єктами інвестиційної діяльності зверх наданої їм законодавством компетенції не допускається. Зокрема, у 2001 р. був прийнятий Закон України "Про внесення змін до деяких законів України з метою усунення випадків ухилення окремих підприємств, створених за участю іноземних інвесторів, від сплати податків, зборів (обов’язкових платежів)” від 20.12.2001 p. № 2899-III. У 2003 р. було видано Указ Президента України "Про додаткові заходи щодо залучення іноземних інвестицій в економіку України”. [22] Він спрямований на подальший розвиток законодавства про іноземні інвестиції. Ним не встановлюються нові правила здійснення інвестиційної діяльності, а лише визначаються заходи, які мають бути здійснені органами виконавчої влади.

Головним Законом України, а саме Конституцією, який прийнятий 1996 р. окреслено повноваження державних органів щодо регулювання та 
координації інвестиційної сфери. Зокрема в останньому зазначено, що Кабінет міністрів України забезпечує проведення фінансової, цінової, інвестиційної та податкової політики; політики у сферах праці й зайнятості населення, соціального захисту, освіти, науки і культури, охорони природи, екологічної безпеки і природокористування [23].

Важливим законом, котрий поліпшує інвестиційну діяльність України, а також створює сприятливий інвестиційний клімат є Закон України "Про додаткові заходи щодо залучення іноземних інвестицій в економіку України" від 2003 р. [24]. В даному акті встановлені та окреслені основні завдання для державних органів, які стосуються підвищення привабливості до інвестицій в економіку України.

Ще одним Законом, який допомагає регулювати питання інвестицій та інвестиційної діяльності $є$ Закон України "Про забезпечення масштабної експансії експорту товарів (робіт, послуг) українського походження шляхом страхування, гарантування та здешевлення кредитування експорту” від 2016 р. [25]. Даним законом врегульовуються питання страхування інвестицій, а саме страхування майнових інтересів інвестора, пов'язаних із втратою інвестицій або їх частини. Відповідно до останнього одними 3 важливих напрямів державної підтримки експортної діяльності є: здійснення Експортнокредитним агентством (далі - ЕКА) операцій із страхування експортних кредитів, прямих інвестицій з України та зовнішньоекономічних договорів (контрактів) від комерційних та некомерційних ризиків, перестрахування та надання гарантій; надання ЕКА кредитів 3 державного бюджету для виплати страхових відшкодувань за договорами страхування експортних кредитів, інвестицій та зовнішньоекономічними договорами (контрактами) від комерційних та некомерційних ризиків. Варто наголосити, що страхування прямих інвестицій з України здійснюється виключно за умови спрямування таких інвестицій на створення інфраструктури, необхідної для розвитку експорту товарів (робіт, послуг) українського походження.

Максимальне спрощення для суб'єкта інвестиційної діяльності порядку отримання послуг, пов'язаних із підготовкою та реалізацією інвестиційних проектів, шляхом запровадження принципу “єдиного вікна" покликаний забезпечити Закон України "Про підготовку та реалізацію інвестиційних проектів за принципом “єдиного вікна” від 21.10.2010 р. № 2623VI, який набрав чинності 01.01.2012 р. [26]. Вказаним Законом визначаються правові та організаційні засади відносин, пов'язаних 3 підготовкою та реалізацією інвестиційних проектів за принципом “єдиного вікна", та передбачається, зокрема, покладання на уповноважений орган функцій взаємодії із суб'єктами надання адміністративних та господарських послуг, що, у свою чергу, значно спростить порядок отримання послуг суб'єктом інвестиційної діяльності, необхідних для подальшої реалізації інвестиційного проекту. 
Окрім цього, Верховною Радою України прийнято Закон України "Про внесення змін до Податкового кодексу України щодо стимулювання інвестицій у вітчизняну економіку", положення якого спрямовані на створення привабливого інвестиційного клімату через звільнення від оподаткування доходів, які виникають у разі валютних коливань при внесенні інвестицій, виражених в іноземній валюті [27].

Варто звернути увагу на ще один важливий Закон України, який регулює інвестиційну діяльність а території України, тобто на Закон України "Про особливості провадження інвестиційної діяльності на території Автономної Республіки Крим" від 2013 р. [28]. Він спрямований на створення сприятливих умов для комплексного та збалансованого розвитку Автономної Республіки Крим шляхом забезпечення ефективного використання ресурсного потенціалу, залучення інвестицій та оптимального здійснення інвестиційної діяльності. Тобто цей Закон визначає особливості провадження інвестиційної діяльності на території Автономної Республіки Крим як невід'ємної частини України.

Оскільки ми все більше пересвідчуємось в актуальності нашого дослідження варто розглянути також Закон України "Про стимулювання інвестиційної діяльності у пріоритетних галузях економіки з метою створення нових робочих місць” від 2012 р. [29]. Закон визначає основи державної політики в інвестиційній сфері протягом 2013-2032 років щодо стимулювання залучення інвестицій у пріоритетні галузі економіки. Закон спрямований на створення умов для активізації інвестиційної діяльності шляхом концентрації ресурсів держави на пріоритетних напрямах розвитку економіки 3 метою запровадження новітніх та енергозберігаючих технологій, створення нових робочих місць, розвитку регіонів.

На сьогодні вникає проблема ефективного розміщення фінансових вкладень інвесторів, для подолання даного негативу прийнято Закон України "Про інститути спільного інвестування" від 2012 р. [30]. Закон спрямований на забезпечення залучення та ефективного розміщення фінансових ресурсів інвесторів і визначає правові та організаційні основи створення, діяльності, припинення суб'єктів спільного інвестування, особливості управління активами зазначених суб'єктів, встановлює вимоги до складу, структури та зберігання таких активів, особливості емісії, обігу, обліку та викупу цінних паперів інститутів спільного інвестування, а також порядок розкриття інформації про їх діяльність.

Що стосується Закону України «Про захист іноземних інвестицій на Україні» від 1991 р., то вказаний законодавчий акт спрямований на захист інвестицій, прибутків, законних прав та інтересів іноземних інвесторів на території України. Законом визначено правовий режим діяльності іноземних інвесторів та гарантії держави щодо здійснення інвестиційної діяльності на території України [31]. 
Також важливе значення має прийнятий 17 лютого 2000 року Закон України «Про усунення дискримінації в оподаткуванні суб'єктів підприємницької діяльності створених 3 використанням майна та коштів вітчизняного походження» № 1457-III, який спрямований на захист конкуренції між суб'єктами підприємницької діяльності, створеними без залучення коштів або майна (майнових чи немайнових прав) іноземного походження, та суб'єктами підприємницької діяльності, створеними за участю іноземного капіталу, забезпечення державного захисту вітчизняного виробника та конституційних прав і свобод громадян України. Вказаним Законом визначено, що спеціальне законодавство України про іноземні інвестиції, а також державні гарантії захисту іноземних інвестицій визначені законодавством України, не регулюють питання валютного, митного та податкового законодавства, чинного на території України, якщо інше не передбачено міжнародними договорами України, згода на обов'язковість яких надана Верховною Радою України (стаття 3 Закону) [32].

Так, у 1992 році було прийнято Закон України «Про загальні засади створення і функціонування спеціальних (вільних) економічних зон» від 13 жовтня 1992 року № 2673-XII, який визначив порядок створення і ліквідації, механізм функціонування спеціальних (вільних) економічних зон на території України, загальні правові і економічні основи їх статусу, а також загальні правила регулювання відносин суб'єктів економічної діяльності цих зон 3 місцевими радами народних депутатів, органами виконавчої влади та іншими органами [33].

Особливістю вітчизняного інвестиційного законодавства $€$ те, що окремі аспекти в інвестиційній сфері, окрім вищевказаних нормативноправових актів, регулюються також нормами господарського, податкового, бюджетного, митного, цивільного й земельного законодавства, правовими актами про приватизацію, цінні папери та фондовий ринок, концесію тощо.

Висновки з даного дослідження і перспективи подальших розвідок у даному напрямі. Отже, на сьогодні в Україні присутня вагома кількість нормативно-правових актів, які врегульовують відносини в інвестиційній сфері, а також варто зазначити, що в Україні в цілому створено належне правове підгрунтя для здійснення інвестиційної діяльності. Всі вищезазначені нормативно-правові акти та законопроекти мають на меті удосконалити регулювання відносин в інвестиційній сфері та мають свій предмет та мету.

Тобто, дана нормативно-правова система, яка сформувалась свідчить про те, що на сьогодні держава вживає низку заходів, які мають на меті створення в Україні сприятливих умов здійснення інвестиційної діяльності саме шляхом закріплення на законодавчому рівні принципів та правил іiі здійснення. Зважаючи на певні проблеми, які присутні в сфері інвестиційної діяльності, органи державної влади намагаються проводити активну роботу щодо регулювання відносин в інвестиційній сфері, а національне інвестиційне 
законодавство набуває рис стабілізаційного характеру. Перспективами подальших досліджень $є$ вдосконалення нормативно-законодавчої бази регулювання інвестиційної безпеки держави.

\section{Лimepamypa:}

1. Мошенський С.I. Інвестиційна безпека в системі забезпечення економічної безпеки держави: поняття, категорії, сутність. / С.І. Мошенський. // Наука молода. - 2008. - №10. C. $166-171$.

2. Макух А. Інвестиційна безпека України в системі світової економічної безпеки. [Електронний ресурс] / А. Макух, Л. Руснак - Режим доступу до ресурсу: http://intkonf.org/makuh-a-rusnak-l-investitsiyna-bezpeka-ukrayini-v-sistemi-svitovoyiekonomichnoyi-bezpeki/.

3. Губенко І.В. Монетарна обумовленість інвестиційної складової економічної безпеки національної економіки. / І.В. Губенко. // Економіка і регіон. - 2012. - №5. - С. 75-80.

4. Акімова Л.М. Система оцінювання показників ефективності державного контролю за економічною діяльністю. Інвестиції: практика та досвід. 2018. № 15. С. 71-76.

5. Акімова Л.М. Напрями взаємоузгодження нормативно-правових актів щодо забезпечення економічної безпеки держави за соціальною та демографічною сферами національного господарства. Інвестииї̈: практика та досвід. 2018. № 16. С. 87-91.

6. Акімова Л.М. Методологічний базис державного управління забезпеченням економічної безпеки України. Інвестиції: практика та досвід. 2018. № 17. С. 67-71.

7. Акімова Л.М. Інструменти та діагностика умов забезпечення економічної безпеки держави інструментами державного управління. Інвестиції: практика та досвід. 2018. № 18. С. 62-66.

8. Акімова Л.М. Імплементація міжнародного досвіду державного управління забезпеченням економічної безпеки держави в Україні. Інвестиції: практика та досвід. 2018. № 19. C. 94-98. DOI: 10.32702/2306-6814.2018.19.94

9. Акімова Л.М. Аналіз тенденцій розвитку економіки держави та їх вплив на економічну безпеку України. Інвестииії: практика та досвід. 2018. № 20. С. 71-75. DOI: 10.32702/2306-6814.2018.20.71

10. Акімова Л.М. Вплив фінансових компаній на фінансово-економічну безпеку держави: міжнародний досвід. Інвестиції: практика та досвід. 2018. № 21. С. 95-100. DOI: $10.32702 / 2306-6814.2018 .21 .95$

11. Акімова Л.М. Аналіз гібридних загроз економічній безпеці України: міжнародний досвід та українські реалії. Інвестииї: практика та досвід. 2018. № 22. С. 110-115. DOI: $10.32702 / 2306-6814.2018 .22 .110$

12. Акімова Л.М. Оцінювання впливу основних інструментів державного регулювання на економічну безпеку України. Інвестиції: практика та досвід. 2018. № 23. С. 113-117. DOI: $10.32702 / 2306-6814.2018 .23 .113$

13. Акімова Л.М. Напрями удосконалення нормативно-правового забезпечення економічної безпеки держави. Інвестищіï: практика та досвід. 2018. № 24. С. 57-62. DOI: $10.32702 / 2306-6814.2018 .24 .57$

14. Акімова Л.М. Державне управління як суб'єкт забезпечення економічної безпеки України: сутність та зміст. Інвестиції: практика та досвід. 2019. № 5. С. 110-115. DOI: $10.32702 / 2306-6814.2019 .5 .110$

15. Акімова Л.М. Система оцінювання показників ефективності державного контролю за економічною діяльністю. Інвестиції: практика та досвід. 2018. № 15. С. 71-76.

16. Акімова Л.М. Податкові пільги та їх вплив на інвестиції в Україні / Л.М. Акімова, В.Б. Рейнська, О. О. Акімов, М. І. Карпа // Фінансово-кредитна діяльність: проблеми теорії 
та практики : збірник наукових праць / Харківський інститут банківської справи УБС НБУ. - Харків : ДВНЗ “Університет банківської справи”. - 2018. - Том. 3. - № 26. - С. 91-101.

17. Закон України «Про інвестиційну діяльність» [Електронний ресурс] - Режим доступу: https://zakon.rada.gov.ua/laws/show/1560-12.

18. Закон України «Про Концепцію регулювання інвестиційної діяльності в умовах ринкової трансформації економіки» [Електронний ресурс] - Режим доступу: https://zakon.rada.gov.ua/laws/show/384-95-\%D0\%BF.

19. Закон України «Про зовнішньоекономічну діяльність» [Електронний ресурс] Режим доступу: https://zakon.rada.gov.ua/laws/show/959-12.

20. Закон України «Про режим іноземного інвестування» [Електронний ресурс] Режим доступу: https://zakon.rada.gov.ua/laws/show/93/96-\%D0\%B2\%D1\%80.

21. Закон України «Конвенція про порядок вирішення інвестиційних спорів між державами та іноземними особами» [Електронний ресурс] - Режим доступу: https://zakon.rada.gov.ua/laws/show/995_060.

22. Закон України «Про внесення змін до деяких законів України з метою усунення випадків ухилення окремих підприємств, створених за участю іноземних інвесторів, від сплати податків, зборів (обов’язкових платежів)» [Електронний ресурс] - Режим доступу: https://zakon.rada.gov.ua /laws/show/2899-14.

23. Закон України «Конституція України» [Електронний ресурс] - Режим доступу: https://zakon.rada.gov.ua/laws/show/254\%D0\%BA/96-\%D0\% B2\%D1\%80\#n1654.

24. Закон України «Про додаткові заходи щодо залучення іноземних інвестицій в економіку України» [Електронний ресурс] - Режим доступу: https://zakon.rada.gov.ua/laws/show/580/2003.

25. Закон України «Про забезпечення масштабної експансії експорту товарів (робіт, послуг) українського походження шляхом страхування, гарантування та здешевлення кредитування експорту» [Електронний ресурс] - Режим доступу: https://zakon.rada.gov.ua/laws/show/1792-19.

26. Закон України «Про підготовку та реалізацію інвестиційних проектів за принципом “єдиного вікна"» [Електронний ресурс] - Режим доступу: https://zakon.rada.gov.ua/laws/show/2623-17.

27. Закон України «Про внесення змін до Податкового кодексу України щодо стимулювання інвестицій у вітчизняну економіку» [Електронний ресурс] - Режим доступу: https://zakon.rada.gov.ua/laws/show/4057-17.

28. Закон України «Про особливості провадження інвестиційної діяльності на території Автономної Республіки Крим » [Електронний ресурс] - Режим доступу: https://zakon.rada.gov.ua/laws/show/639-18.

29. Закон України «Про стимулювання інвестиційної діяльності у пріоритетних галузях економіки з метою створення нових робочих місць» [Електронний ресурс] - Режим доступу: https://zakon.rada.gov.ua/laws /show/5205-17.

30. Закон України «Про інститути спільного інвестування» [Електронний ресурс] Режим доступу: https://zakon.rada.gov.ua/laws /show/5080-17.

31. Закон України «Про захист іноземних інвестицій на Україні» [Електронний ресурс] - Режим доступу: https://zakon.rada.gov.ua/laws/ show/1540\%D0\%B0-12.

32. Закон України «Про усунення дискримінації в оподаткуванні суб’єктів підприємницької діяльності створених 3 використанням майна та коштів вітчизняного походження» [Електронний ресурс] https://zakon.rada.gov.ua/laws/show/1457-14.

33. Закон України «Про загальні засади створення і функціонування спеціальних (вільних) економічних зон» [Електронний ресурс] - Режим доступу: https://zakon.rada.gov.ua/laws/show/2673-12. 


\section{References:}

1. Moshenskyi, S. (2008). Investytsiina bezpeka v systemi zabezpechennia ekonomichnoi bezpeky derzhavy: poniattia, katehorii, sutnist [Investment security in the system of ensuring the economic security of the state: concepts, categories, essence] Nauka moloda - Science is young, 10. 166-171 [in Ukrainian].

2. Makukh, A. and Rusnak, L. Investytsiina bezpeka Ukrainy $\mathrm{v}$ systemi svitovoi ekonomichnoi bezpeky [Investment security of Ukraine in the world economic security system]. Retrieved from http://intkonf.org/makuh-a-rusnak-l-investitsiyna-bezpeka [in Ukrainian].

3. Hubenko, I. (2012). Monetarna obumovlenist investytsiinoi skladovoi ekonomichnoi bezpeky [Monetary conditionality of the investment component of economic security of the national economy] Ekonomika i rehion - Economy and region,5, 75-80 [in Ukrainian].

4. Akimova, L. (2018), "System of estimation of indicators of efficiency of state control of economic activity”, Investytsiyi: praktyka ta dosvid, vol. 15, pp. 71-76.

5. Akimova, L. (2018), "Directly to the mutual agreement of normative and legal activities to forget the economic behavior of the holding for the social than demographic spheres of the national center”, Investytsiyi: praktyka ta dosvid, vol. 16, pp. 87-91.

6. Akimova, L. (2018), "Methodological basis of government department of maintenance of economic safety of Ukraine”, Investytsiyi: praktyka ta dosvid, vol. 17, pp. 67-71.

7. Akimova, L. (2018), "Instruments and diagnostics of conditions for ensuring economic security of the state by means of public administration”, Investytsiyi: praktyka ta dosvid, vol. 18, pp. 62-66.

8. Akimova, L. (2018), "Implementation of international experience of state management of ensuring the economic security of the state in Ukraine”, Investytsiyi: praktyka ta dosvid, vol. 19, pp. 94-98. DOI: 10.32702/2306-6814.2018.19.94

9. Akimova, L. (2018), “Analysis of trends in the development of the state economy and their impact on Ukraine's economic security”, Investytsiyi: praktyka ta dosvid, vol. 20, pp. 71-75. DOI: $10.32702 / 2306-6814.2018 .20 .71$

10. Akimova, L. (2018), "The influence of financial companies on the financial and economic security of the state: international experience", Investytsiyi: praktyka ta dosvid, vol. 21, pp. 95100. DOI: $10.32702 / 2306-6814.2018 .21 .95$

11. Akimova, L. (2018), "Analysis of hybrid threats to economic security of Ukraine: international experience and ukrainian realities”, Investytsiyi: praktyka ta dosvid, vol. 22, pp. 110115. DOI: 10.32702/2306-6814.2018.22.110

12. Akimova, L. (2018), "Evaluation of the influence of the key instruments of the state regulation on economic security of Ukraine”, Investytsiyi: praktyka ta dosvid, vol. 23, pp. 113-117. DOI: 10.32702/2306-6814.2018.23.113

13. Akimova, L. (2018), "Directions of improving the regulatory and legal support of economic safety of the state", Investytsiyi: praktyka ta dosvid, vol. 24, pp. 57-62. DOI: $10.32702 / 2306-6814.2018 .24 .57$

14. Akimova, L. (2019), "State management as a subject of providing economic security of Ukraine: situation and content”, Investytsiyi: praktyka ta dosvid, vol. 5, pp. 110-115. DOI: 10.32702/2306-6814.2019.5.110

15. Akimova, L. (2018), "System of estimation of indicators of efficiency of state control of economic activity”, Investytsiyi: praktyka ta dosvid, vol. 15, pp. 71-76.

16. Akimova L.M., Reinska V.B., Akimov O.O. (2018) Tax preferences and their influence on the investment in Ukraine . Collection of scientific papers Financial and Credit ActivityProblems of Theory and Practice. - № 26. Part. 3. - pp. 91-101 [in Ukrainian]. 
17. Zakon Ukrainy «Pro investytsiinu diialnist»[ The Law of Ukraine «On investment activity»] (n.d.). zakon. rada. gov. ua. Retrieved from https://zakon.rada.gov.ua/laws/show/156012.

18. Zakon Ukrainy «Pro Kontseptsiiu rehuliuvannia investytsiinoi diialnosti v umovakh rynkovoi transformatsii ekonomiky» [ The Law of Ukraine «On the concept of regulation of investment activity in the conditions of market transformation of the economy»] (n.d.). zakon. rada. gov. ua. Retrieved from https://zakon.rada.gov.ua/laws/show/384-95-\%D0\%BF.

19. Zakon Ukrainy «Pro zovnishnoekonomichnu diialnist» [ The Law of Ukraine «On foreign economic activity»] (n.d.). zakon. rada. gov. ua. Retrieved from https://zakon.rada.gov.ua/laws/show/959-12.

20. Zakon Ukrainy «Pro rezhym inozemnoho investuvannia» [ The Law of Ukraine «On foreign investment regime»] (n.d.). zakon. rada. gov. ua. Retrieved from https://zakon.rada.gov.ua/laws/show/93/96-\%D0\%B2\%D1\%80.

21. Zakon Ukrainy «Konventsiia pro poriadok vyrishennia investytsiinykh sporiv mizh derzhavamy ta inozemnymy osobamy» [ The Law of Ukraine "Convention on the procedure for settlement of investment disputes between states and foreign persons»] (n.d.). zakon. rada. gov. ua. Retrieved from https://zakon.rada.gov.ua/laws/show/995_060.

22. Zakon Ukrainy «Pro vnesennia zmin do deiakykh zakoniv Ukrainy z metoiu usunennia vypadkiv ukhylennia okremykh pidpryiemstv, stvorenykh za uchastiu inozemnykh investoriv, vid splaty podatkiv, zboriv (oboviazkovykh platezhiv)» [ The Law of Ukraine "On amendments to certain laws of Ukraine to eliminate cases of evasion of individual enterprises created with foreign investors' participation from taxes, fees (mandatory payments)»] (n.d.). zakon. rada. gov. ua. Retrieved from https://zakon.rada.gov.ua/laws/show/2899-14.

23. Zakon Ukrainy «Konstytutsiia Ukrainy» [ The Law of Ukraine «Constitution of Ukraine»] (n.d.). zakon. rada. gov. ua. Retrieved from https://zakon.rada.gov.ua/laws/show/254\%D0\%BA/96-\%D0\%B2\%D1 \%80\#n1654.

24. Zakon Ukrainy «Pro dodatkovi zakhody shchodo zaluchennia inozemnykh investytsii v ekonomiku Ukrainy» [ The Law of Ukraine «On additional measures to attract foreign investments into the economy of Ukraine»] (n.d.). zakon. rada. gov. ua. Retrieved from https://zakon.rada.gov.ua /laws/show/580/2003.

25. Zakon Ukrainy «Pro zabezpechennia masshtabnoi ekspansii eksportu tovariv (robit, posluh) ukrainskoho pokhodzhennia shliakhom strakhuvannia, harantuvannia ta zdeshevlennia kredytuvannia eksportu» [ The Law of Ukraine «On ensuring large-scale export expansion of goods (works, services) of Ukrainian origin through insurance, guarantee and cheaper export credit»] (n.d.). zakon. rada. gov. ua. Retrieved from https://zakon.rada.gov.ua/laws/show/1792-19.

26. Zakon Ukrainy «Pro pidhotovku ta realizatsiiu investytsiinykh proektiv za pryntsypom "iedynoho vikna"» [ The Law of Ukraine "On preparation and implementation of single window investment projects»] (n.d.). zakon. rada. gov. ua. Retrieved from https://zakon.rada.gov.ua/laws/show/2623-17.

27. Zakon Ukrainy «Pro vnesennia zmin do Podatkovoho kodeksu Ukrainy shchodo stymuliuvannia investytsii u vitchyznianu ekonomiku» [ The Law of Ukraine «On amendments to the tax code of Ukraine on promotion of investments in the domestic economy»] (n.d.). zakon. rada. gov. ua. Retrieved from https://zakon.rada.gov.ua/laws/show/4057-17.

28. Zakon Ukrainy «Pro osoblyvosti provadzhennia investytsiinoi diialnosti na terytorii Avtonomnoi Respubliky Krym» [ The Law of Ukraine «On peculiarities of investment activity in the territory of the Autonomous Republic of Crimea»] (n.d.). zakon. rada. gov. ua. Retrieved from https://zakon.rada.gov.ua /laws/show/639-18.

29. Zakon Ukrainy «Pro stymuliuvannia investytsiinoi diialnosti u priorytetnykh haluziakh ekonomiky z metoiu stvorennia novykh robochykh mists» [ The Law of Ukraine «On stimulating 
investment activity in priority sectors of the economy in order to create new jobs»] (n.d.). zakon. rada. gov. ua. Retrieved from https://zakon.rada.gov.ua/laws/show/5205-17.

30. Zakon Ukrainy «Pro instytuty spilnoho investuvannia» [ The Law of Ukraine «On joint investment institutions»] (n.d.). zakon. rada. gov. ua. Retrieved from https://zakon.rada.gov.ua/laws/show/5080-17.

31. Zakon Ukrainy «Pro zakhyst inozemnykh investytsii na Ukraini» [ The Law of Ukraine «On protection of foreign investments in Ukraine»] (n.d.). zakon. rada. gov. ua. Retrieved from https://zakon.rada.gov.ua/laws/show/1540\% D0\%B0-12.

32. Zakon Ukrainy «Pro usunennia dyskryminatsii V opodatkuvanni subiektiv pidpryiemnytskoi diialnosti stvorenykh $\mathrm{z}$ vykorystanniam maina ta koshtiv vitchyznianoho pokhodzhennia» [ The Law of Ukraine "On elimination of discrimination in taxation of entrepreneurship activities created using property and means of domestic origin»] (n.d.). zakon. rada. gov. ua. Retrieved from https://zakon.rada.gov.ua/laws/show/1457-14.

33. Zakon Ukrainy «Pro zahalni zasady stvorennia i funktsionuvannia spetsialnykh (vilnykh) ekonomichnykh zon» [ The The Law of Ukraine «On general principles of creation and functioning of special (free) economic zones»] (n.d.). zakon. rada. gov. ua. Retrieved from https://zakon.rada.gov.ua/laws/ show/2673-12. 